\title{
Towards Managing Firm Performance through Enterprise Risk Management Practices and Staff Competence: An Empirical Study from the Banking Sector
}

\author{
Habil Slade Ogalo \\ Arab Open University, Bahrain Branch, Bahrain \\ drhabilslade@aou.org.bh
}

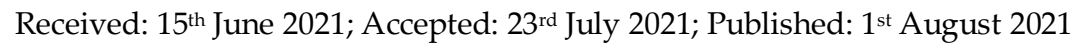

Abstract: This study was aimed to measure the impact of enterprise risk management practices on firm performance following the moderation of staff competence. The present study proposed five hypotheses, three direct and two moderating. For measuring hypotheses and objectives, the current research targeted bank officers in the Kingdom of Bahrain's banking sector. A total final sample of 349 was used in primary analyses selected through simple random sampling. Current research shows significant positive effects of risk culture and risk knowledge sharing on the firm 's (financial and non-financial) performance of banks in the Kingdom of Bahrain. Similarly, the first moderation strengthens the relationship between risk knowledge sharing and firm performance through staff competence. In addition, the second moderation hypothesis does not strengthen the relationship between risk culture and firm performance with the moderating effect of staff competence. The current research findings are supported under the resource-based view with several theoretical and practical implications for researchers and industry practitioners.

Keywords: Risk Culture; Risk Knowledge Sharing; Staff Competence; Firm Performance

\section{Introduction}

In the current era, the performance of the business organization can be re-examined through the different aspects (Malik et al., 2020). Similarly, corporate failure has instigated many researchers to explore the connection between risk management initiatives and risk committees (Manhart et al.,2020). The collapse of Enron, WorldCom, and Lehman Brothers were the worst corporate scandals of the 21st century (Young $\&$ Perez, 2002). Boniface and Ibe (2012) found that complexities surrounding corporate organizations, the strength to manage present and future risk revelations play a vital role in the firms' survival. Consequently, business firms can perceive future changes and competitiveness from globalization, deregulations, and the competitive challenges from the external environment (Shecterle, 2010).

Moreover, it is also observed that the aversive risk firms cannot be performed proactively in the risk assessment process to mitigate the poor results and control the elements affecting firm performance (Naeem et al., 2020). Similarly, According to Kirtley and Mahonay (2020), change is the necessary element to meet the customer expectation, performance assessment, engagement imperatives, risk management 
skills, and exploitation of the distinct competencies to enhance the current business performance era. Hence, these are the critical issues that bring risk management as a limelight factor of business performance (Rostami, Sommerville, Wong, \& Lee, 2015). In addition, it is also explored by the Asian financial crisis of 1997 that further supported by Global Financial Crises in 2008, that risk management could be the potential strategy for firms' survival. Moreover, these financial crises, the recent pandemic situation of covid-19 has shaken the whole world confidence and created a dire need for the best risk management initiatives for survival and growth (Kristinae et al., 2020).

Central Bank of Nigeria (CBN) 2010 explained that financial institution has the significant contribution to accelerate the economy that enhances the wealth of the households and business units to hold and survive in the market's volatile conditions. Despite the significant role of the financial intuitions, including investment banks and other financial institutes, firms are struggling to sustain in this pandemic situation. According to Okadapo and Richard (2012) stated that around the world, it is evident that firms face all the challenges efficiently with the strong intervention of the intermediaries. Similarly, the banking sector of the kingdom of Bahrain has also witnessed difficulties in maintaining performance.

The uncertainties surrounding firms have attracted business leaders' attention to the search for risk management strategies that can improve firm performance. The following are some of the practical problems that motivate the study. Malik et al. (2020) delineated that significant change in the global market especially in the emerging countries, including national and multinational firms instigated, redesign their business strategies and initiate the risk management steps to sustain in the competitive environment (Manhart et al.,2020; Zurich 2011). Despite several efforts and legislation, strong uncertainty tends to obscure organizations' ability to handle the danger adequately and retain a convenient degree of management still exists (KPMG, 2013; Zurich, 2011). The urge to identify the best risk management strategies that businesses can rely upon to carry out business operations efficiently has attracted several firms' attention. Secondly, weak risk management and poor compliance with regulatory provisions are part of the issues that seriously weaken the effectiveness of business firms. In fact, lack of compliance with internal and external regulatory provisions in several economies has become a threat to the global financial systems (Oghojafora, Olayemia, Okonjia, \& Okolieb, 2010). A global survey conducted by KPMG International in 2011 revealed significant gaps and compliance in the financial institutions of several countries (KPMG, 2011).

Researchers have studied the impact of ERM practices on organizational performance (Manab \& Ghazali, 2013; Mikes \& Kaplan, 2014). From the theoretical perspectives, ERM practices and organizational performance have a consistent and inconsistent relationship (Togok, Ruhana, \& Zainuddin, 2014; Bertinetti, Cavezzali, \& Gardenal, 2013). Similarly, Baxter, Bedard, Hoitash, and Yezegel, (2013) indicated the positive effect of ERM practices on firm performance. While few of studies found an insignificant effect of ERM (Ballantyne, 2013; Hafizuddin-Syah et al., 2014; Pagach \& Warr, 2010). Despite the reported benefits of ERM implementation, the extent to which ERM adds value to organizations is yet to be resolved.

Similarly, a large number of studies have examined some success factors that influence firm performance. Up till now, a few of the risk management success aspects that were studied include business reputations, remuneration, trust (Carey, 2001); top management support, communication, technology (Grabowski \& Roberts, 1999); organizational culture, leadership factors (Manab \& Kassim, 2012; Ranong \& Phuenngam, 2009; Yaraghi \& Langhe, 2011); cross-functional staff, risk management base (Manab, Othman, \& Kassim, 2012) among others. However, some studies investigated the influence of the risk management system, risk knowledge sharing, staff competence, and innovativeness on firm performance. These variables are directly linked to the practical problems raised earlier in this study. Keeping these problems in consideration, this research has investigated the effect of risk culture, risk knowledge sharing on firm 
performance, the moderation of staff or employee competence on the relationship of risk culture, risk knowledge sharing with banks (financial and non-financial) performance.

\subsection{Objectives of the Research}

a) To assess the direct effect of risk culture on firm performance (financial and non-financial).

b) To investigate the impact of risk knowledge sharing on firm performance (financial and nonfinancial).

c) To assess the impact of moderation by staff or employee competence to enhance the relationship of risk culture and risk knowledge sharing with firm performance (financial and non-financial).

\section{Literature Review}

\subsection{Firm Performance}

Researchers have paid considerable attention to various factors that influence individual and organizational performance (Kong, Antwi-Adjei, \& Bawuah, 2020). Performance is the most important indicator that could be used to estimate and assess the final outcome of the individual or firm development. In the current scenario, the business environment has drastically changed to cope with the more concerned organizations' challenges (Asghar, Wasim, Qazi, \& Rasool, 2020). The global business environment has forced business firms to situate their business goals toward providing quality services. Moreover, companies face a huge competition in technology, innovation, latent customer needs, and advanced production methods (Hakkak \& Ghodsi, 2015). Firm performance in financial and managerial literature was seen as one of the key reasons for researchers (Gavrea, Ilieş, \& Stegerean, 2011). According to Saeidi, Sofian, Zaleha and Abdul (2014), firm success is a term that describes how well a company achieves its goals. It reveals how companies spend additional time.

A company's performance is an indicator for evaluating and comparing the progress of an enterprise in achieving market targets and all its players (Antony \& Bhattacharyya, 2010). Meanwhile, Asat, Maruhun, Haron, and Jaafar (2015) narrated that it allows businesses to accomplish their goals effectively and efficiently by leveraging available capital. Several researchers have used numerous performance metrics for assessing organizational performance (Khan, Kamran, \& Imran, 2020; Nomran \& Haron, 2020; Elsiddig, 2020).

As a result, tests have shown that the valuation of ERM is influenced both by financial performance and non-financial performance (Gates, Nicolas \& Walker, 2012). Power (2009) argued that several reasons behind the failure of the risk management "impoverished conception of risk appetite. Hence, this study will use subjective financial and non-financial performance to gauge ERM's influence, including risk culture and risk knowledge sharing on the financial and non-financial performance of the banking opera sating in the Kingdom of Bahrain. The measurement was based on a bank employees' perception of the firm's status (increase or decrease in performance). Thus, in the present study, firm performance (financial and non-financial performance) is the outcome that shows the optimum level of performance in managerial decisions, business goals, and earnings. Besides this, current research has tested the moderating role of staff or employee competence between the relationship of risk culture and risk knowledge sharing with firm performance (financial and non-financial).

\subsection{Hypothesis Development}

\subsubsection{Risk Culture and Firm Performance}

Since then, many studies have continued to assess the impact of risk culture on business performance (Ma, Tang, Wang, \& Gao, 2020; Bui, Chen, Hsu, \& Lin 2020; Bui, Fang, \& Lin, 2018). In fact, it is observed 
in the worldwide level that culture is the comprehensive component that designs the organizational culture, relationship building among people within the organization and reflects the accepted norms of the society, which constitutes the stability, future certainty and success of the firms (Cameron \& Quinn, 2011). One of the financial firm's major challenges is to ensure that sound risk culture is embedded in its business strategies and objectives (EY Global Limited, 2014). Consistent with this, Cameron and Quinn (2011) asserted that corporate culture is among the most central competitive factors that organizations possess. It is difficult if not impossible, to name even a single highly successful company that does not have a unique, readily visible organizational culture.

Similarly, the results of a joint survey (Risk Management Association/Protiviti Inc) revealed that risk culture is a key challenge to improving risk management practices and firm performance, especially in the context of financial institutions (Protiviti Inc., 2014). Similarly, Protiviti Inc. (2014) discussed that more than 50 percent of respondents believed that risk culture is one of the most important and potential elements of the risk management workstream rather than an integral part of the business strategies and execution plans. Aksoy, Apak, Eren and Korkmaz (2014) revealed that organizational culture and organizational learning on firm performance are examined in turkey, and study results found that organizational culture components have a strong effect on an organization's efficiency and performance. Therefore, it can be inferred that considering risk culture as a stand-alone appendage that focuses only on risk management function may not improve business performance. Firms with strong cultures experience higher performance depending on the level of stability of the environment. Davidson (2003) was not found significant in some of the dimensions of the organizational culture with a South African investment bank's financial performance. However, the organizational culture dimension of consistency traits was found to be correlated and associated with firm performance.

Similarly, De Caluwe and Dooren (2013) revealed that organizational culture has no significant effect on firm performance. In addition, Uzkurt, Kumar, Kimzan, and Eminoglu (2013) explored that innovation has a mediating role between organizational culture and firm performance. Thus, given the inconsistencies in the literature, it is clear that culture is an ambiguous construct that needs further investigation. The present study examined culture by focusing on those norms and values that focus on firm performance.

Hypothesis 1: Risk culture will significantly predict firm performance

\subsubsection{Risk Knowledge Sharing and Firm Performance}

There is an argument as to what aspect of knowledge-sharing organizations should concentrate on. Knowledge sharing may be internal within an organization or external between organizations. Either of the two may be beneficial to business performance. However, Ritala, Olander, Michailova and Husted (2014) empirically examined the effect of external knowledge sharing on firm performance. The study revealed that external knowledge sharing has a positive influence on firm performance. The study further argued that though external knowledge sharing positively influences firm performance, organizations must be cautious to prevent accidental leakages that may undermine business secretes.

On the other hand, sharing knowledge within an organization may enhance synergy and create better performance opportunities. Internal knowledge sharing can lead to a sustainable competitive gain for the firm (Casimir, Lee, \& Loon, 2012). Information sharing internally is crucial in any financial institution, and it helps firms to achieve business success. Hsu (2008) found a positive impact of organizational knowledge sharing on firm performance using 256 companies from Taiwan. The study revealed that knowledge sharing could positively improve firm performance. Liao, Ma, Lee, and Ke (2011) contended that sharing information improves the banks' operational efficiency and performance. Consistent with this, Wang, Wang and Liang (2014) investigated the effect of knowledge sharing (KS) on firm performance. A similar finding was reported by Rehman, Baloch, Afeef, and Saleem (2015), who stated that sharing information 
has a positive effect on risk management among the performance of the employees in Pakistan's banking sector. Using top managers as respondents, the study reported that information sharing has a significant positive effect on banks' financial performance. It is reasonable to argue that a sound organizational structure that encourages risk information sharing will positively impact performance. Risks knowledge sharing among employees, customers, and the media may help firms control the large scale of risks that may hugely affect their operations.

Hypothesis 2: Risk knowledge sharing will significantly predict firm performance

\subsubsection{Direct and Moderating Role of Staff Competence}

Various studies were conducted to examine the connection of competence both to employee performance and to firm performance. For example, Debellis et al. (2020) discussed that the willingness to utilize human resources positively significantly impacts firms' performance and overall employees of the firm put their maximum efforts to achieve firm performance. Ismail and Abidin (2010) examined the influence of staff competence on performance based on a sample of 1136 employees of different cadre in Malaysia from the private service sector. The study findings indicated that staff competence has significant effects on their performance. Though the study focuses on the workers' performance, it can be assumed that an organization's performance largely depends on the capacity of its workforce. Another study conducted by Long and Ismail (2011) examined the influence of staff competence in the context of the Malaysian manufacturing industry. The study indicated that competencies (such as strategic contribution, business knowledge) significantly influence performance. Amenta and Ramsey (2010) reported that staff competence significantly influences a firm's effectiveness. In the same vein, Yaraghi and Langhe (2011) found a significant positive effect of staff competence on firm performance. Accordingly, study by Ekrot, Kock, and Gemünden (2016) established a positive relationship between a project manager's competencies and the average success of a project. The study further established the importance of meta-competence in establishing a formal lesson learned system. In a qualitative study, John and Ackah (2015) examined the effect of staff competence on firm performance. The study utilized 280 respondents from the pharmaceutical industry in Ghana. The study found a positive effect of staff competence on firm performance. In a service-driven industry such as finance, staff competency directly relates to higher firm performance. Despite the increasing propensity in the conception of staff competence in increasing performance, staff competence as a risk management success factor has received little attention. Though employee competence is difficult to measure, it is key to the achievement of higher firm performance (Liu, Ruan, \& Xu, 2005; Vakola, Soderquist, \& Prastacos, 2007). Hence, based on the evidence regarding the role of staff competence in the different organizational cultures of business enterprises, different settings of knowledge sharing cannot be ignored. Therefore, in this research, it is assumed that employee competence can moderate the relationship of risk culture, risk knowledge sharing with firm performance and can be predicted as:

Hypothesis 3: Staff competence has a significant effect on firm performance.

Hypothesis 4: Risk knowledge sharing will increase more firm performance when there is higher employee competence.

Hypothesis 5: Positive risk culture will improve the firm performance when there is higher employee competence.

\section{Methodology}

\subsection{Instruments}

The questionnaire was structured as the research instrument. The first section covered questions about the demographics of respondents, and the second section covered items about the framework of study firm 
performance (12 items), risk culture ( 8 items), risk knowledge sharing ( 5 items), and staff competence (5 items). For measuring culture, items were adapted from KPMG, 2011. Accordingly, for measuring risk knowledge sharing, Rodriguez and Edwards (2009a, b) instrument was used. Besides this, staff competence was measured with Dooley and Fryxel (1999) and Rettab, Brik and Mellahi (2009) and Gates, Nicolas and Walker (2012) to examine firm performance.

\subsection{Data Collection}

Data were collected from the staff working at the banking sector of the Kingdom of Bahrain. The sample for the current study was 382 was selected through simple random sampling. For having a desirable response rate, 450 instruments were distributed and 370 were received back, showing a response rate of $82.22 \%$. After screening data through SPSS23, a final 349 respondents list was used for the final model assessment. Respondents were selected through simple random sampling as list of staff was used from the attendance record. Further detail regarding demographic data is illustrated in table 1.

Table 1. Demographic Data of Respondents $(n=349)$

\begin{tabular}{lll}
\hline Factor & Frequency & Percentage \\
\hline Gender & 280 & $80.23 \%$ \\
Male & 69 & $19.77 \%$ \\
Female & & \\
Age & 35 & $10.03 \%$ \\
26years-30 years & 150 & $42.98 \%$ \\
31years-35 years & 130 & $37.25 \%$ \\
36years-40 years & 34 & $9.74 \%$ \\
41years-45 years & & \\
Qualification & 60 & $17.19 \%$ \\
College diploma & 180 & $51.58 \%$ \\
Graduate & 109 & $31.23 \%$ \\
Post graduate & & \\
Marital status & 130 & $37.25 \%$ \\
Unmarried & 219 & $62.75 \%$ \\
Married & & \\
\hline
\end{tabular}

\subsection{Method and Data Analysis}

The present study adopted two main approaches for model assessment. At first, measurement model assessment by using the PLS algorithm to check reliability and validity. Second, hypotheses were tested through the structural model (Anderson \& Gerbing 1988) by applying bootstrapping technique using Smart PLS 3.2.8.

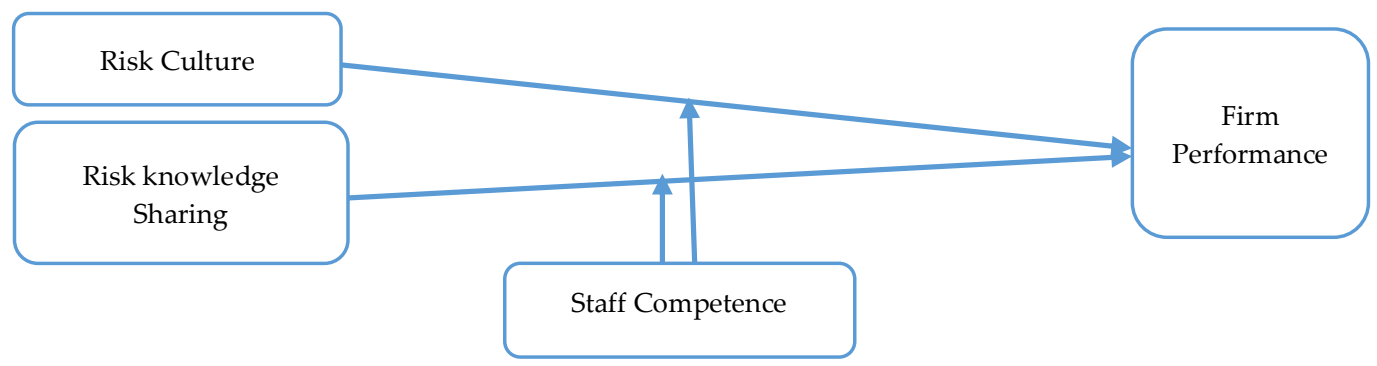

Figure 1. Research Framework 


\section{Findings}

\subsection{Assessment of Measurement Model}

Based on Fornell and Larcker (1981) reliability and validity were examined. In criteria, validity was anticipated when discriminant validity with a score of 0.70 and above and construct can have validity when its average variance extract has a value of 0.50 and above. Both reliability and validity were assumed and were found to be in the recommended range. Validity scores, reliability values, s and loadings are presented in table 2.

Table 2. Measurement Model

\begin{tabular}{|c|c|c|c|c|}
\hline \multirow{2}{*}{$\frac{\text { Latent Variable }}{\text { Firm performance (F \& NF) }}$} & \multirow{2}{*}{ Loading } & \multirow{2}{*}{$\frac{\mathrm{CR}}{0.901}$} & \multicolumn{2}{|l|}{ AVE } \\
\hline & & & 0.532 & \\
\hline FP1 & 0.634 & & & \\
\hline FP12 & 0.687 & & & \\
\hline FP2 & 0.689 & & & \\
\hline FP5 & 0.778 & & & \\
\hline FP6 & 0.772 & & & \\
\hline FP7 & 0.776 & & & \\
\hline FP8 & 0.783 & & & \\
\hline FP9 & 0.70 & & & \\
\hline Risk Knowledge sharing & & 0.92 & 0.697 & \\
\hline RKS1 & 0.824 & & & \\
\hline RKS2 & 0.821 & & & \\
\hline RKS3 & 0.864 & & & \\
\hline RKS4 & 0.844 & & & \\
\hline RKS5 & 0.82 & & & \\
\hline Risk Culture & & & 0.856 & 0.506 \\
\hline $\mathrm{RMC2}$ & 0.609 & & & \\
\hline RMC3 & 0.659 & & & \\
\hline RMC4 & 0.587 & & & \\
\hline RMC5 & 0.868 & & & \\
\hline RMC6 & 0.867 & & & \\
\hline RMC8 & 0.618 & & & \\
\hline Staff Competence & & 0.849 & 0.539 & \\
\hline SCP1 & 0.517 & & & \\
\hline SCP2 & 0.574 & & & \\
\hline SCP3 & 0.83 & & & \\
\hline $\mathrm{SCP} 4$ & 0.838 & & & \\
\hline SCP5 & 0.839 & & & \\
\hline
\end{tabular}

Table 2 also shows loadings for each item used in the research. The firm performance was measured with 12 items, out of which four items (FP3, FP4, FP10, and FP11) were deleted due to lower loadings. Besides this, risk culture was measured with 8 items, whereby two items (RMC1 and RMC7) were deleted during the model assessment due lower factor loadings. Besides this, discriminant validity was also checked through AVE's square root by following Chin (1998). The current study also found significant discriminant validity. Further details are available in table 3.

Table 3. Discriminant Validity (correlation matrix) square root of AVE

\begin{tabular}{|c|c|c|c|c|c|c|c|c|c|c|}
\hline & & FP & & RKS & & RMC & SCP & & SCP*RKS & SCP*RMC \\
\hline$\overline{\mathrm{FP}}$ & & 0.730 & & & & & & & & \\
\hline RKS & & 0.701 & & 0.835 & & & & & & \\
\hline $\mathrm{RMC}$ & & 0.419 & & 0.336 & & 0.711 & & & & \\
\hline SCP & & 0.663 & & 0.699 & & 0.391 & 0.734 & & & \\
\hline $\mathrm{SCP}^{*} \mathrm{RKS}$ & -0.216 & & -0.367 & & -0.116 & -0.431 & & 1.000 & & \\
\hline $\mathrm{SCP}^{*} \mathrm{RMC}$ & & -0.119 & & -0.142 & & -0.077 & -0.255 & & 0.365 & 1.000 \\
\hline
\end{tabular}


Along with the square root of AVE, discriminant validity was also assessed through HTMT criteria (Henseler, Ringle, \& Sarstedt 2015). The recommended maximum values of HTMT are HTMT0.85 and HTMT0.90 (Henseler, Ringle, \& Sarstedt, 2015). Results regarding HTMT values in the current study all values were well below the criteria of HTMT0.90. further details are presented in table 4.

Table 4. HTMT Values

\begin{tabular}{lllll}
\hline & FP & RKS & RMC & SCP \\
\hline FP & ---- & & & \\
RKS & 0.753 & ---- & --- & \\
RMC & 0.363 & 0.291 & 0.412 & --- \\
SCP & 0.729 & 0.799 & . & \\
\hline
\end{tabular}

After assessment of reliability and validity, the current study also checked model assessment with R2 and f2. Based on Falk and Miller (1992) R2 value shows a change in the dependent variable due to independent variables. Current study findings regarding R2 value show firm performance with 0.571 . Besides this current study also checked effect size through $\mathrm{f} 2$ value. F2 values show the effects of each independent variable on the dependent variable. Risk knowledge sharing with $\mathrm{f} 2$ of 0.253 , risk culture with f2 0.043 , and staff competence was with $\mathrm{f} 2$ of 0.116 . The measurement model is represented in figure 2 .

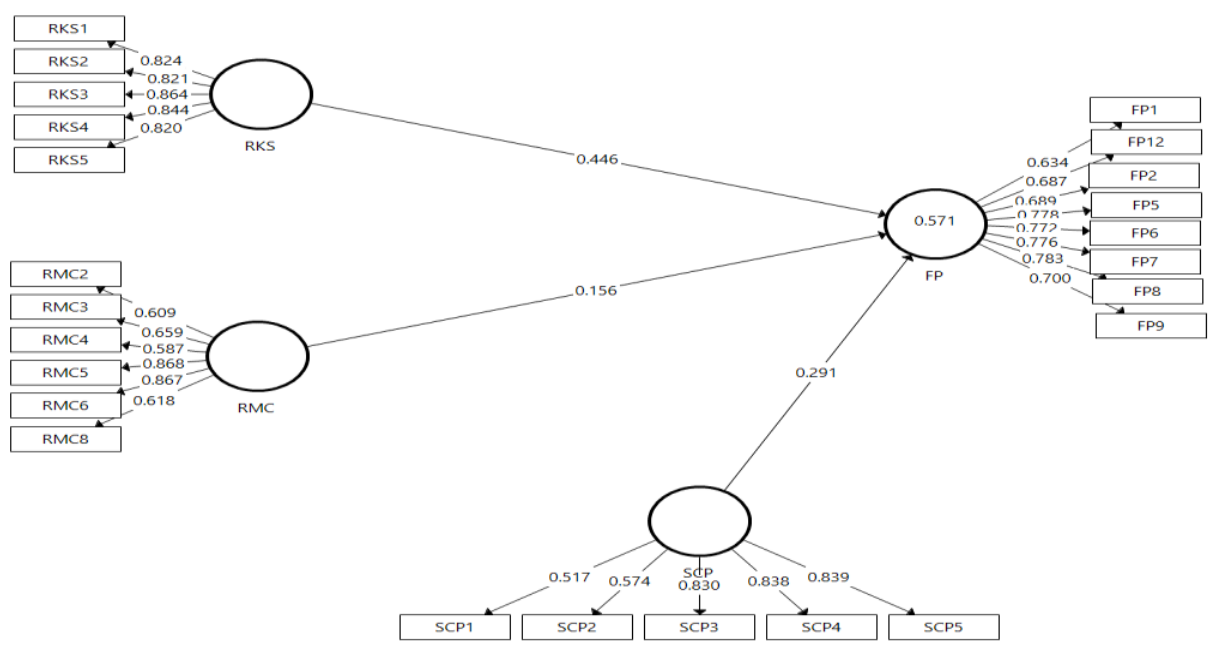

Figure 2. Measurement Model

\subsection{Structural Model Assessment}

After the measurement model assessment, the current study assessed the structural model for hypothesis testing, results of which are presented in table 5 and figure 3 below.

Table 5. Structural Model Assessment

\begin{tabular}{lllll}
\hline Hypotheses & beta & t value & p value & Results \\
\hline H1: $\mathrm{RMC} \rightarrow \mathrm{FP}$ & 0.147 & 3.337 & 0.001 & Supported \\
$\mathrm{H} 2: \mathrm{RKS} \rightarrow \mathrm{FP}$ & 0.461 & 7.919 & 0.000 & -do- \\
$\mathrm{H} 3: \mathrm{SCP} \rightarrow \mathrm{FP}$ & 0.332 & 5.713 & 0.000 & -do- \\
$\mathrm{H} 4: \mathrm{SCP}{ }^{\mathrm{R} K S} \rightarrow \mathrm{FP}$ & 0.083 & 2.183 & 0.029 & -do- \\
$\mathrm{H} 5: \mathrm{SCP}$ RMC $\rightarrow$ FP & 0.001 & 0.017 & 0.986 & Not Supported \\
\hline
\end{tabular}

The bootstrapping results found a significant link between risk culture and firm performance in $\mathrm{H} 1$ ( $\beta$ $=0.147, \mathrm{t}$ value $=3.337, \mathrm{p}$-value $=0.001)$, accepting hypothesis one. Similarly, a significant positive relationship between Risk knowledge sharing and firm performance was found in $\mathrm{H} 2$ ( $\beta=0.0 .461$, $\mathrm{t}$ value $=7.919, \mathrm{p}$-value $=0.000$ ). In addition, results regarding $\mathrm{H} 3$ testing staff competence effect on firm 
performance was also significant $(\beta=0.332, \mathrm{t}$ value $=5.713, \mathrm{p}$-value $=0.000)$. Besides these direct relationships, the current research also tested two moderating effects through staff competence as a moderator between risk cultures, risk knowledge sharing with firm performance. Current study found significant results in $\mathrm{H} 4(\beta=0.083, \mathrm{t}$ value $=2.183$, $\mathrm{p}$-value, $=0.029)$. This shows that staff competence has moderated the relationship of risk knowledge sharing with firm performance. In contrast, the current research found insignificant results $(\beta=0.001$, $\mathrm{t}$ value $=0.017$, $\mathrm{p}$-value $=0.986)$, showing $\mathrm{H} 5$ to be not supported. This means that staff competence could not moderate the relationship of risk culture with firm performance. Furthermore, graphical presentation is provided in figure 3 (structural model) and figure 4 \& 5 (interaction plot of SCP and RMC.)

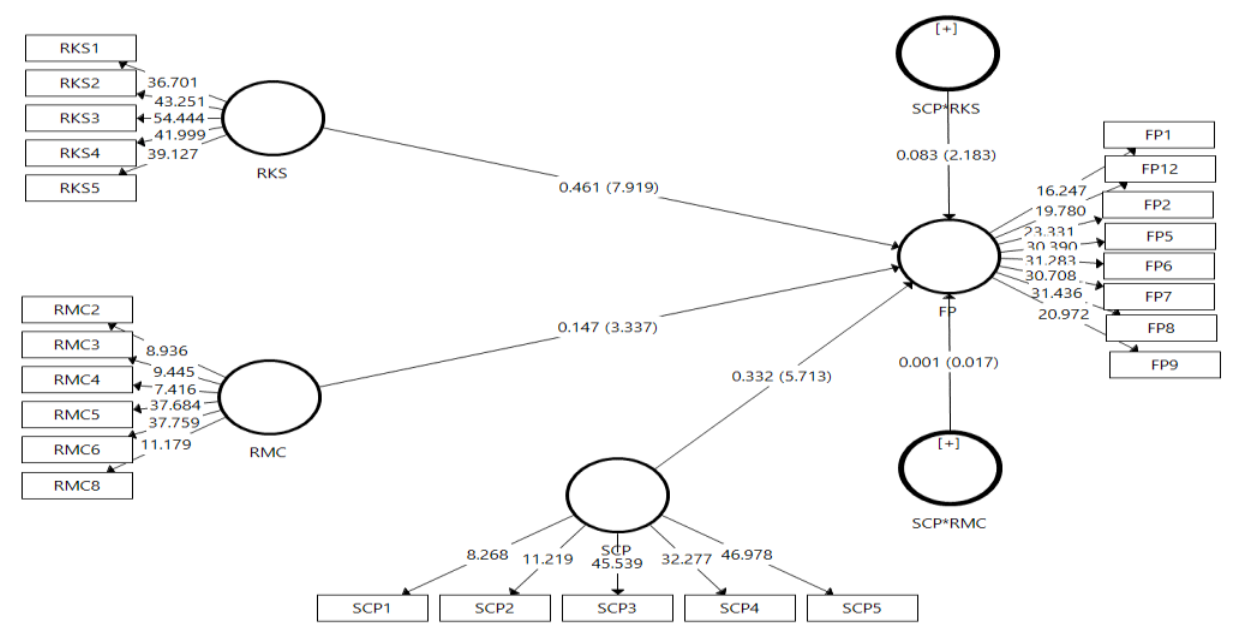

Figure 3. Structural Model

\section{Discussion}

The current study has enriched empirical evidence in the body of knowledge by adding enterprise risk management practices in the research model as an independent variable under the umbrella of resource-based view theory (Barney, 1991). The current study has contributed by outlining significant findings regarding the role of risk culture, risk knowledge sharing, and staff competence on firm (financial and non-financial) performance. The significant findings of H1, stating the effect of risk culture on firm performance, the results are parallel to prior literature (Aksoy, Apak, Eren, \& Korkmaz, 2014), stating the strong effect of culture on firm performance. The findings indicate that positive risk culture is helpful in better firm performance. Besides this, significant results in $\mathrm{H} 2$ regarding the effect of risk knowledge sharing with firm performance also were supported by the existing empirical literature (Rehman, Baloch, Afeef \& Saleem, 2015; Wang, Wang \& Liang, 2014); Liao, Ma, Lee \& Ke, 2011). Based on the existing literature and current study findings, the researcher argues that knowledge-sharing system in banks will improve firm performance. In assessing the effect of staff competence on firm performance, the present research also found significant results, which were also supported by existing literature (Ekrot, Kock, \& Gemünden, 2016; John \& Ackah, 2015).

Fortunately, staff competence was also found to strengthen the relationship between the Risk knowledge sharing effect and firm performance. According to Galdeano et al. (2019), staff competence instigates employees to perform at their optimum level to grow the firm. It is also observed that when the staff has a knowledge-sharing environment in the organization, it ultimately enhances the firm's performance in the volatile environment. Similarly, positive significant hypothesis 4 has shown that 
Bahrain's banking system has significantly focused on employee training and development, enabling them to perform better in the competitive environment.
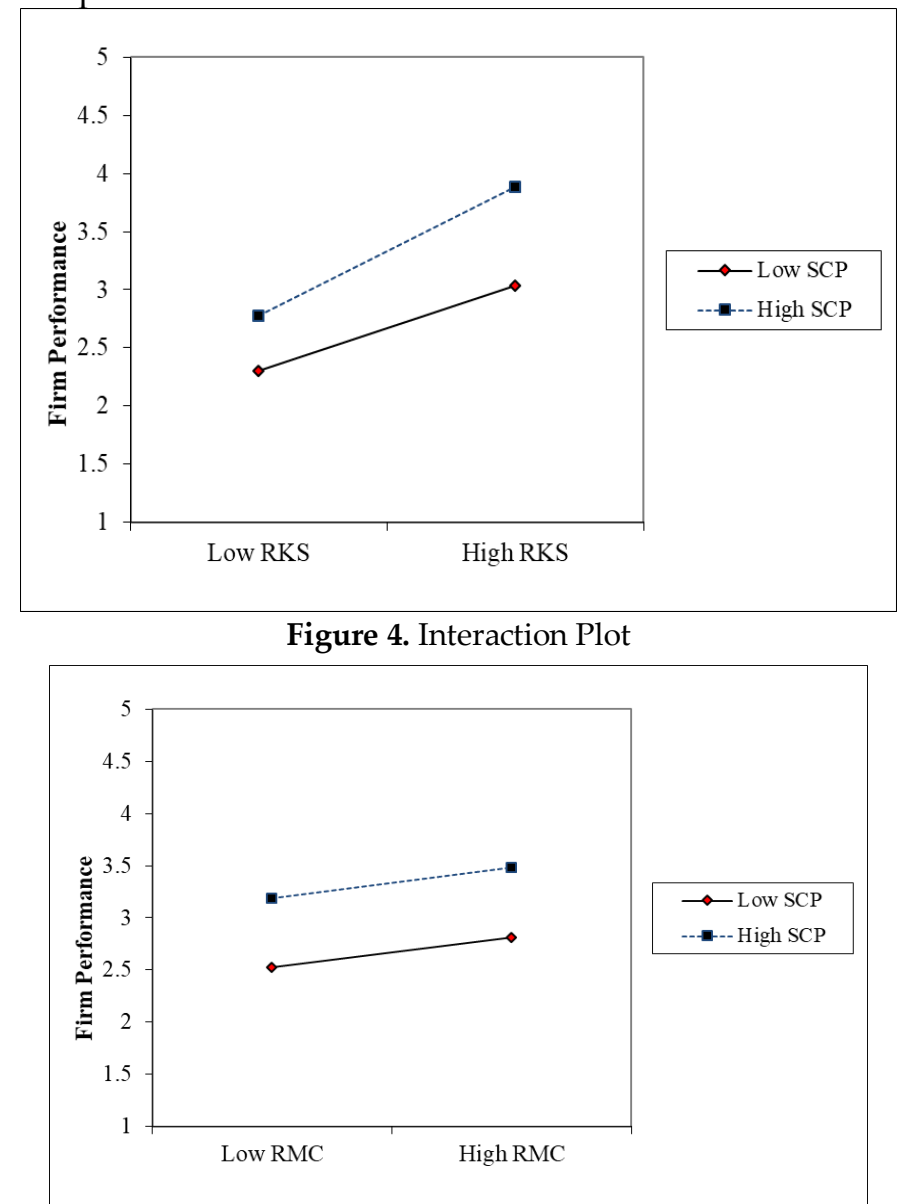

Figure 5. Interaction Plot

Unfortunately, staff competence could not strengthen the relationship between the Risk culture effect and firm performance. Furthermore, this study concludes that the insignificant relationship between RMC and firm performance is affected by staff competence. The results could support the RBV theory because RBV focused on the VRIN that instigates the employees' ability not to imitate any other human being. Consequently, it is explored from the findings of the current study that employees must educate about Risk culture in Bahrain's banking environment, which educate them on how to control the sudden effects of the Risk, which can be produced through the uncertain condition of the financial market in the emerging countries. Moreover, it has shown that banks can perform better in the finance arrange activities through ERM. Henceforth, enhanced benefits can be obtained by a business, particularly banks, in the context of our study from ERM practices. Accordingly, this competence can help them express more dedication and immersion towards ERM practices to enhance financial performance.

\subsection{Implications}

This research work delivered evidence for the hypothesized theoretical relationships in the research framework. The study assessed the influence of ERM framework implementation and ERM success factors on the banking sector of the Kingdom of Bahrain. Furthermore, current research has developed a significant moderating effect of staff competence on the relationship of risk knowledge sharing with firm performance 
and an insignificant moderating effect of staff competence on the relationship of risk culture with firm performance in the banking sector of the Kingdom of Bahrain. Notably, considering the link of RBV with the current research framework, ERM factors are valuable for firm performance. ERM success factors (RBV) explain financial institutions' performance (banks) in the Kingdom of Bahrain. Specifically, the study contributed to the literature stream to understand how some important success factors (risk culture, risk knowledge sharing) influence firm performance.

Besides, strong theoretical implications, the current research also offers significant practical implications. Based on the findings, the study aims to benefit regulators, financial institutions, investors, shareholders, and other practitioners in understanding how ERM practices effectively influence firm performance. It has further assessed the challenges and the benefits of ERM practices in financial institutions. Having discussed at length how ERM success factors influence firm performance, the study recommends the need for financial institutions and regulatory agencies to develop policies and strategies that will effectively improve ERM practices in the banking sector of Kingdom of Bahrain.

\subsection{Limitations and Future Scope}

Along with the contributions of this study, the research has few limitations. Firstly, this study covers only banks of the Kingdom of Bahrain, whereas there are other financial institutes to be covered to assess enterprise risk management practices (risk culture and risk knowledge sharing). Hence future researchers may also consider other financial institutions in their studies alongside banks. In addition, the present research is cross-sectional (Sekaran \& Bougie 2010) and the responses were based on the single time collection process. Future studies on a similar framework may be tested with longitudinal data for better results about risk management in banks operating in the Kingdom of Bahrain.

\section{Conclusion}

This research has made a valuable contribution to how the banking sector can consider ERM practices to increase firm performance. Besides this, current research has contributed a significant direct effect of ERM practices on firm performance. Furthermore, a valuable moderating effect has also been found in current research. This research has communicated empirical evidence based on literature that can be helpful for business success.

\section{References}

Aksoy, M., Apak, S., Eren, E., \& Korkmaz, M. (2014). Analysis of the effect of organizational learning based on organisational culture on performance, job satisfaction and efficiency: A field study of banking sector. International Journal of Academic Research, 6(1), 301-313

Amenta, E., \& Ramsey, K. M. (2010). Institutional theory. Handbook of Politics, 15-39

Anderson, J. C., \& Gerbing, D. W. (1988). Structural equation modeling in practice: A review and recommended twostep approach. Psychological bulletin, 103(3), 411-423.

Antony, J. P., \& Bhattacharyya, S. (2010). Measuring organizational performance and organizational excellence of SMEs Part 2: an empirical study on SMEs in India. Measuring Business Excellence, 14(3), 42-52.

Asat, S. H., Maruhun, E. N. S., Haron, H., \& Jaafar, M. (2015). Enterprise risk management (ERM) and organisational performance: The case of housing developers in Malaysia. In MARIM International Conference, Langkawi

Asghar, B., Wasim, A., Qazi, U., \& Rasool, A. (2020). Financial and Non-Financial Practices Driving Sustainable Firm Performance: Evidence from Banking Sector of Developing Countries. Sustainability, 12(15), 6164.

Ballantyne, R. (2013). An Empirical Investigation into the Association Between Enterprise Risk Management and Firm Financial Performance. Lawrence Technological University

Barney, J. (1991). Firm resources and sustained competitive advantage. Journal of Management, 17(1), 99-120. 
Baxter, R., Bedard, J. C., Hoitash, R., \& Yezegel, A. (2013). Enterprise risk management program quality: determinants, value relevance, and the financial crisis. Contemporary Accounting Research, 30(4), 1264-1295

Bertinetti, G. S., Cavezzali, E., \& Gardenal, G. (2013). The Effect of The Enterprise Risk Management Implementation on The Firm Value of European Companies (No. 10/2013).

Boniface, U., \& Ibe, I. G. (2012). Enterprise risk management and performance of Nigeria's brewery industry. Developing Country Studies, 2(10), 60-67.

Bui, D. G., Chen, Y. S., Hsu, H. H., \& Lin, C. Y. (2020). Labor unions and bank risk culture: evidence from the financial crisis. Journal of Financial Stability, 51, 100782.

Bui, D. G., Fang, Y., \& Lin, C. Y. (2018). The influence of risk culture on firm returns in times of crisis. International Review of Economics \& Finance, 57, 291-306.

Cameron, K. ., \& Quinn, R. . (2011). Diagnosing and changing organizational culture based on the competing Values framework, 3rd edition. San Francisco, CA: John Wiley and Sons

Carey, A. (2001). Effective risk management in financial institutions: the Turnbull approach. Balance Sheet, 9(3), 24-27

Casimir, G., Lee, K., \& Loon, M. (2012). Knowledge sharing: Influences of trust, commitment and cost. Journal of Knowledge Management, 16(5), 740-753.

CBN. (2010). Financial stability report. Abuja Nigeria. Retrieved from https://www.cbn.gov.ng

Chin, W. W. (1998). The partial least squares approach to structural equation modeling. Modern Methods for Business Research, 295(2), 295-336.

Davidson, G. M. (2003). The Relationship Between Organizational Culture and Financial Performance in A South African Investment Bank. Unversity of South Africa

De Caluwé, C., \& Dooren, W. Van. (2013). Do organisations matter? A multilevel analysis explaining perceptions of organizational performance. In 11th Public Management Research Conference. Madison, Wisconsin.

Debellis, F., De Massis, A., Petruzzelli, A. M., Frattini, F., \& Del Giudice, M. (2020). Strategic agility and international joint ventures: The willingness-ability paradox of family firms. Journal of International Management, 100739.

Dooley, R. S., \& Fryxell, G. E. (1999). Attaining decision quality and commitment from dissent: The moderating effects of loyalty and competence in strategic decision-making teams. Academy of Management Journal, 42(4), 389-402.

Ekrot, B., Kock, A., \& Gemünden, H. G. (2016). Retaining project management competence - Antecedents and consequences. International Journal of Project Management, 34(2), 145-157.

Elsiddig Ahmed, I. (2020). The qualitative characteristics of accounting information, earnings quality, and Islamic banking performance: Evidence from the gulf banking sector. International Journal of Financial Studies, 8(2), 30.

EY Global Limited. (2014). Developing effective and sustainable risk cultures in Banks. New York. Retrieved from www.ey.com/Publication/vwLUAssets/EY

Falk, R. F., \& Miller, N. B. (1992). A Primer for Soft Modeling. University of Akron Press.

Fornell, C., \& Larcker, D. F. (1981). Structural equation models with unobservable variables and measurement error: Algebra and statistics. Journal of Marketing and Research 18(3), 382-388.

Galdeano, D., Ahmed, U., Fati, M., Rehan, R., \& Ahmed, A. (2019). Financial performance and corporate social responsibility in the banking sector of Bahrain: Can engagement moderate?. Management Science Letters, 9(10), 1529-1542.

Gates, S., Nicolas, J., \& Walker, P. L. (2012). Enterprise risk management: A process for enhanced management and improved performance. Management Accounting Quarterly, 13(3), 28-38

Gavrea, C., Ilieş, L., \& Stegerean, R. (2011). Determinants of organizational performance: The case of Romania. Management \& Marketing Challenges for the Knowledge Society, 6(2), 285-300

Grabowski, M., \& Roberts, K. (1999). Risk mitigation in virtual organizations. Organizational Science, 10(6), 704-722

Hafizuddin-Syah, B. A. M., Abdul-Hamid, M., Janor, H., \& Yatim, P. (2014). The implementation of enterprise risk management (ERM) and firm performance: Evidence from Malaysian technology firms. In The 16th Malaysian Finance Association Conference (MFA2014): Financial Systems Re-Generation: MAPS, GAPS and TRAPS

Hakkak, M., \& Ghodsi, M. (2015). Development of a sustainable competitive advantage model based on balanced scorecard. International Journal of Asian Social Science, 5(5), 298-308

Henseler, J., Ringle, C. M., \& Sarstedt, M. (2015). A new criterion for assessing discriminant validity in variance-based structural equation modeling. Journal of the Academy of Marketing Science, 43(1), 115-135.

$\mathrm{Hsu}$, I. C. (2008). Knowledge sharing practices as a facilitating factor for improving organizational performance through human capital: A preliminary test. Expert Systems with Applications, 35(3), 1316-1326 
Ismail, R., \& Abidin, S. Z. (2010). Impact of workers' competence on their performance in the Malaysian private service sector. Business and Economic Horizons, 2, 25-30

John, A. O., \& Ackah, O. (2015). Employee's competency and organizational performance in the pharmaceutical industry: An empirical study of pharmaceutical firms in Ghana, International Journal of Economics, Commerce and Management, 3(3), 1-9

Khan, M. J., Kamran, M., \& Imran, M. (2020). Impact of Ownership Structure and Board Composition on Firm Performance in Banking Sector of Pakistan. Journal of Banking and Finance, 3(1), 1-11.

Kirtley, J., \& O'Mahony, S. (2020). What is a pivot? Explaining when and how entrepreneurial firms decide to make strategic change and pivot. Strategic Management Journal.

Kong, Y., Antwi-Adjei, A., \& Bawuah, J. (2020). A systematic review of the business case for corporate social responsibility and firm performance. Corporate Social Responsibility and Environmental Management, 27(2), $444-454$.

KPMG. (2011). Risk managment: A driver of enterprise value in emerging environment. Retrieved from https://erm.ncsu.edu/library/article/improvechallenges-survey

KPMG. (2013). Expectations of risk Management outpacing capabilities: It's time for action. Retrieved from https://www.kpmg.com

Kristinae, V., Wardana, I., Giantari, I., \& Rahyuda, A. (2020). The role of powerful business strategy on value innovation capabilities to improve marketing performance during the COVID-19 pandemic. Uncertain Supply Chain Management, 8(4), 675-684.

Liao, K., Ma, Z., Lee, J.-Y. J., \& Ke, K. (2011). Achieving mass customization through trust- driven information sharing: a supplier's perspective. Management Research Review, 34(5), 541-552.

Liu, X., Ruan, D., \& Xu, Y. (2005). A study of enterprise human resource competence appraisement. Journal of Enterprise Information Management, 18(3), 289-315.

Long, C. S., \& Ismail, W. K. W. (2011). An analysis of the relationship between HR professionals' competencies and firms' performance in Malaysia. The International Journal of Human Resource Management, 22(5), $1054-1068$.

Ma, X., Tang, Z., Wang, D., \& Gao, H. (2020). The influence of risk culture on the performance of international jointventure securities. Sustainability, 12(7), 2603.

Malik, M. F., Zaman, M., \& Buckby, S. (2020). Enterprise risk management and firm performance: Role of the risk committee, Journal of Contemporary Accounting E Economics, 16(1), 100178.

Manab, N. A., \& Ghazali, Z. (2013). Does Enterprise Risk Management Create Value. Journal of Advanced Management Science, 1(4), 358-362.

Manab, N. A., \& Kassim, I. (2012). Moderating effect of leadership on a success factors of enterprise-wide risk management practices. In 3rd International Conference on Business and Economics (pp. 1727-1741)

Manab, N. A., Othman, S. N., \& Kassim, I. (2012). Enterprise-wide risk management best practices: The critical success factors. International Journal of Sustainable Development, 4(3), 1-10

Manhart, P., Summers, J. K., \& Blackhurst, J. (2020). A meta-analytic review of supply chain risk management: assessing buffering and bridging strategies and firm performance. Journal of Supply Chain Management, 56(3), 66-87.

Mikes, A., \& Kaplan, R. S. (2014). Towards a Contingency Theory of Enterprise Risk Management. Harvard Business School Working Paper

Naseem, T., Shahzad, F., Asim, G. A., Rehman, I. U., \& Nawaz, F. (2020). Corporate social responsibility engagement and firm performance in Asia Pacific: The role of enterprise risk management. Corporate Social Responsibility and Environmental Management, 27(2), 501-513.

Nomran, N. M., \& Haron, R. (2020). A systematic literature review on Shari'ah governance mechanism and firm performance in Islamic banking. Islamic Economic Studies.

Oghojafora, A. E. B., Olayemia, O. O., Okonjia, S. P., \& Okolieb, J. U. (2010). Poor corporate governance and its consequences on the Nigerian banking sector. Serbian Journal of Managenet, 5(2), 243-250

Oladapo, A., \& Richard, O. (2012). The implications of global financial crisis on the Nigerian capital market performance: An empirical investigation (2000-2008). European Journal of Humanities and Social Sciences, 16(1), 1-18

Pagach, D., \& Warr, R. (2010). The Effects of Enterprise Risk Management on Firm Performance (Vol. 9). Retrieved from http://ssrn.com/abstract $=1155218$

Power, M. (2009). The risk management of nothing. Accounting, Organizations and Society, 34(6-7), 849-855 
Protiviti Inc. (2014). Establishing and nurturing an effective risk culture: Enabling the chief risk officer's success. Retrieved from http://www.protiviti.com/enUS/Documents/White-Papers/Risk-Solutions/CRO-Series4Establishing-andNurturing-an-Effective-Risk-Culture-Protiviti.pdf

Ranong, Rp. N., \& Phuenngam, W. (2009). Critical Success Factors for Effective Risk Management Procedures In Financial Industries. Umeå University

Rehman, A., Baloch, Q. B., Afeef, M., \& Saleem, M. (2015). Relationship between information sharing and risk management practices with financial performance: Evidence from Pakistani banking sector. Journal of Managerial Sciences, 9(2), 138-146.

Rettab, B., Brik, A. Ben, \& Mellahi, K. (2009). A study of management perceptions of the impact of corporate social responsibility on organisational performance in emerging economies: The case of Dubai. Journal of Business Ethics, $89,371-390$.

Ritala, P., Olander, H., Michailova, S., \& Husted, K. (2014). Knowledge sharing, knowledge leaking and relative innovation performance: An empirical study. Technovation, 35, 22-31.

Rodriguez, E., \& Edwards, J. S. (2009a). Applying knowledge management to enterprise risk management: Is there any value in using KM for ERM? Journal of Risk Management in Financial Institutions, 2(4), 427-437.

Rodriguez, E., \& Edwards, J. S. (2009b). Knowledge management and enterprise risk management implementation in financial services. In Enterprise Risk Management 1-17. Retrieved from www.ermsymposium.org/2009/pdf/

Rostami, A., Sommerville, J., Wong, L. I., \& Lee, C. (2015). Risk management implementation in small and medium enterprises in the UK construction industry. Engineering, Construction and Architectural Management, 22(1), 91-107.

Saeidi, P., Sofian, S., Zaleha, S., \& Abdul, B. (2014). A proposed model of the relationship between enterprise risk management and firm performance. International Journal of Information Processing and Management, 5(2), 70-80.

Sekaran, U., \& Bougie, R. (2010). Research Methods for Business: A Skill Building Approach (5th ed.). UK: John Wiley \& Sons, Inc.

Shecterle, R. (2010). Toyota supply chain lacked risk management oversight. Industry Week

Togok, S. H., Ruhana, C. I., \& Zainuddin, S. (2014). Review of enterprise risk management (ERM) Literature. In International Conference on Technology and Business Management, March 24-26 University of Malaya.1-13

Vakola, M., Soderquist, K. E., \& Prastacos, G. P. (2007). Competency management in support of organisational change. International Journal of Manpower, 28(3/4), 260-275.

Wang, Z., Wang, N., \& Liang, H. (2014). Knowledge sharing, intellectual capital and firm performance. Management Decision, 52(2), 230-258.

Yaraghi, N., \& Langhe, R. G. (2011). Critical success factors for risk management systems. Journal of Risk Research, 14(5), 551-581.

Yaraghi, N., \& Langhe, R. G. (2011). Critical success factors for risk management systems. Journal of Risk Research, 14(5), 551-581

Young, S., \& Perez, E. (2002). Finance chief of WorldCom got high marks on Wall Street. Wall Street Journal, P. B1.

Zurich. (2011). Risk management in a time of global uncertainty. Harvard Business Review, 1-29.

(C) 2021 by the author(s). Published by Annals of Contemporary Developments in Management \& HR (ACDMHR), under the terms and conditions of the Creative Commons Attribution (CC BY) license which can be accessed at http://creativecommons.org/licenses/by/4.0. 